\title{
Alkohol 代謝さ甲狀腺機能さの關係に就て
}

\author{
第 1 編 甲狀腺機能と血液 Alkohol
}

\author{
水 姓 龍 夫 \\ (北海道大學醫學部藥理學教室[主任滇崎呚授]) \\ （昭和二十三年八月十四日受付）
}

\begin{abstract}
緒
需

生體內新陳代謝に密接不離の關倸を有する甲狀腺が Alkohol 代謝殊に負荷 Alkohol の體內消費に如何なる影 響を及ぼすが極めて與味がある。

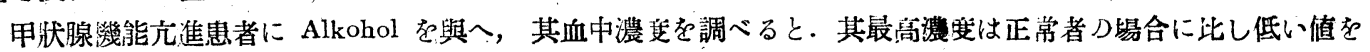

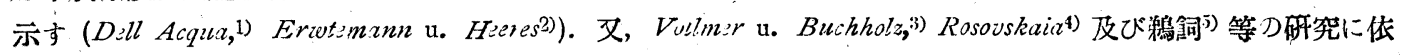
ると，動物に於ては Thyroxin が負荷 Alkohol の體肉消費を促准して居る等である. 反之, Thyroxin は負荷

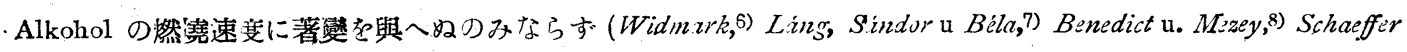
et Le Breton $\left.n^{9}\right)$, 逆に Alkohol 酸化速变を減少せしめると云云學者さへある (Dontcheff(10)). 從つて此問題に關 しては未だ一定の結論に到達して居ない.

他方, 甲狀腺劑刀效果は甲状腺剔出後に最も著明に現はれ，正常侍に效果つ少い事を先人11-21) は警告して居

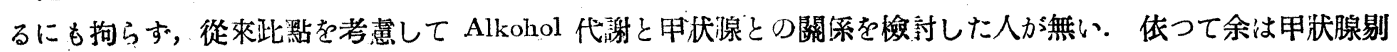

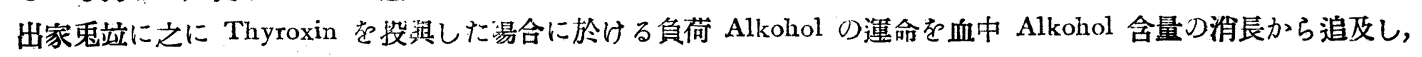

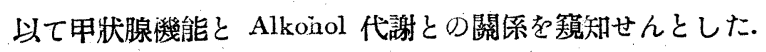

\section{管驗村料及び笛䲆方法}

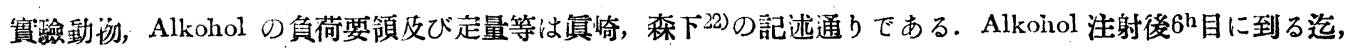

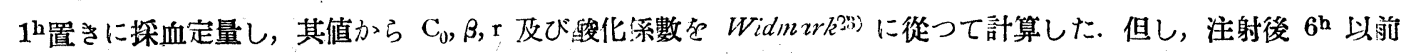

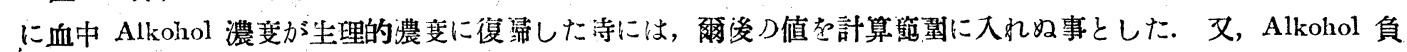

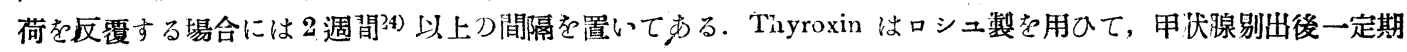

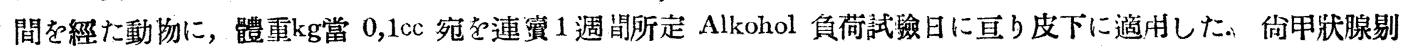
出手䔎は無麻醉つ下にて而も完全に行はれた。

\section{實 驗 成 績}

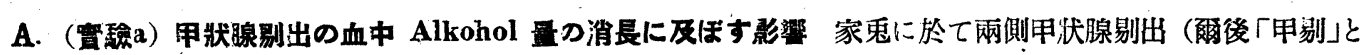
略記）を行つて甲状腺幾能脫茖古起さしめ，之が血中 Alkohol（以下门ア」と略記）の消長に及ぼす影響を䚈察し

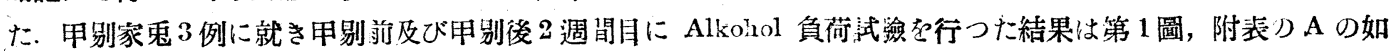

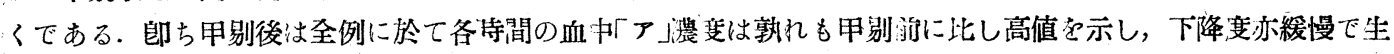

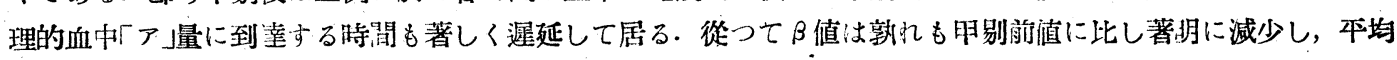

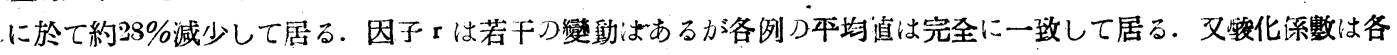

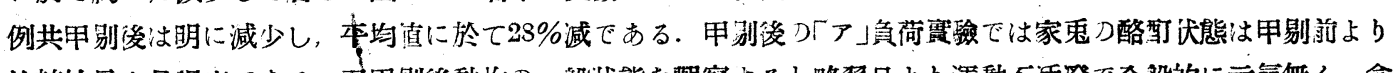

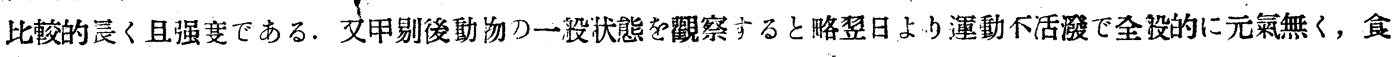

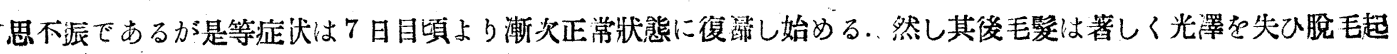


坿 表. 甲狀腺機能と血中「ア」量の消長.

\begin{tabular}{|c|c|c|c|c|c|c|c|}
\hline \multirow{2}{*}{$\begin{array}{l}\text { 螋 } \\
\text { 驗 }\end{array}$} & \multirow{2}{*}{$\begin{array}{l}\text { 家鬼 } \\
\text { 番號 }\end{array}$} & \multirow{2}{*}{ 處 置（甲 剔） } & \multirow{2}{*}{ 體 重 $(k g)$} & 計 算 & 值 $(\mathrm{g} / \mathrm{L})$ & \multirow{2}{*}{ 因 子 } & \multirow{2}{*}{$\begin{array}{l}\text { 酸化係數 } \\
(\mathrm{mg} / \mathrm{kg}, \mathrm{h})\end{array}$} \\
\hline & & & & $\mathrm{C}_{0}$ & $\beta$ & & \\
\hline \multirow{8}{*}{$\mathbf{A}$} & \multirow{2}{*}{2} & & 2,70 & 0,808 & $.0,0027$ & 0,99 & 160 \\
\hline & & 後 2 週 & 2,53 & 0,870 & 0,0019 & 0,91 & 104 \\
\hline & \multirow{2}{*}{4} & & 2,82 & 1,105 & 0,0046 & 0,72 & 199 \\
\hline & & 後 2 週 & 2,46 & 0,973 & 0,0026 & 0,82 & 128 \\
\hline & \multirow{2}{*}{11} & & 2,42 & 1,262 & 0,0046 & 0,63 & 174 \\
\hline & & 後 2 週 & 2,03 & 1,300 & 0,0032 & 0,61 & 117 \\
\hline & \multirow{2}{*}{ 平均 } & & 2,65 & 1,015 & 0,0036 & 0,78 & 168 \\
\hline & & 後 2 週 & ' $\quad 2,34$ & 1,048 & $0,00 \Sigma 6$ & 0,78 & 122 \\
\hline \multirow{15}{*}{ B } & \multirow{3}{*}{3} & & 2,43 & 1,182 & 0,0041 & 0,67 & 165 \\
\hline & & 後 2 週 & 2,37 & 0,938 & 0,0027 & 0,85 & 138 \\
\hline & & 後3週十チロキシン1週 & 1,83 & 1,256 & 0,0042 & 0,63 & 159 \\
\hline & \multirow{3}{*}{6} & 前 & 2,35 & 1,025 & 0,0042 & 0,78 & 197 \\
\hline & & 後 2 週 & 2,06 & 1,260 & 0,0033 & 0,63 & 125 \\
\hline & & 後3週十ナロキシン 1 週 & 1,97 & 1,564 & 0,0044 & 0,51 & 135 \\
\hline & \multirow{3}{*}{9} & 前 & 2,25 & 0,914 & 0,0033 & 0,87 & 172 \\
\hline & & 後 2 週 & 1,68 & 0,815 & 0,0024 & 0,98 & 141 \\
\hline & & 後3週十チロキシン1週， & 1,55 & 1,314 & 0,0036 & 0,60 & 130 \\
\hline & \multirow{3}{*}{10} & & 2,48 & 1,246 & 0,0042 & 0,64 & 161 \\
\hline & & 後 2 週 & 1,88 & 1,203 & 0,0031 & 0,66 & 123 \\
\hline & & 後3週十チロキシン1週 & 1,78 & 1,380 & 0,0038 & 0,58 & 132 \\
\hline & \multirow{3}{*}{$\begin{array}{l}\text { 平 } \\
\text { 均 }\end{array}$} & & 2,38 & 1,065 & 0,0037 & 0,74 & 164 \\
\hline & & 後 2 週 & 2,00 & 1,053 & 0,0029 & 0,76 & 132 \\
\hline & & 後3週十ナロキシン1週 & 1,78 & 1,356 & 0,0038 & 0,58 & 133 \\
\hline \multirow{14}{*}{$\mathbf{C}$} & \multirow{3}{*}{14} & 前 & $.2,32$ & 1,073 & 0,0031 & 0,74 & 138 \\
\hline & & 後1週十キロキシン1週 & 1,75 & 1,400 & 0,0040 & 0,57 & 137 \\
\hline & & 後 4 週 & 1,98 & 1,581 & 0,0037 & 0,50 & 111 \\
\hline & \multirow{3}{*}{15} & 前 & 2,78 & 0,846 & 0,0029 & 0,94 & 164 \\
\hline & & 後1週十チロキシン 1 週 & 2,35 & 1,559 & 0,0053 & 0,51 & 162 \\
\hline & & 後 4 週 & 2,35 & 1,016 & 0,0024 & 0,78 & 112 \\
\hline & \multirow{3}{*}{18} & 前 & 2,23 & 1,799 & 0,0048 & 0,44 & 127 \\
\hline & & 後1週十チロキシン1週 & 2,34 & 1,531 & 0,0045 & 0,52 & 140 \\
\hline & & 後 4 週 & 2,10 & 0,832 & 0,0024 & 0,96 & 138 \\
\hline & \multirow{2}{*}{19} & 前 & 2,20 & 1,277 & 0,0027 & 0,62 & 100 \\
\hline & & 後1週十テロ゙キシン1週 & 2,00 & 0,863 & 0,0030 & 0,92 & 166 \\
\hline & \multirow{3}{*}{$\begin{array}{l}\text { 平 } \\
\text { 均 }\end{array}$} & 前 & 2,44 & 1,215 & 0,0034 & 0,65 & 133 \\
\hline & & 後1週十チロキシン1週 & 2,15 & 1,454 & 0,0043 & 0,55 & 142 \\
\hline & & 後 4 週 & 2,14 & 1,143 & 0,0028 & 0,70 & 118 \\
\hline
\end{tabular}


り易く體溫體重の減少を示した例 をあつた.

\section{B. 甲尉媵 Thyroxin を技興し} た場合の血中「ア」量の消長

（弪驗b）甲剔 3 , 週後より1週間 Thyroxin を連續注射した場合: 先つ 4 例の家鬼 $(3,6,9,10$ 號 $)$ に 就き甲剔後 2 週目にAlkohol 傎荷 試驗を行ひ，次で 1 週間經過後 Thyroxin 1 週間連續注射し其 最終日に再び Alkohol 負荷試驗 を行つた結果は第 2 圖及び附表の Bに示す如くである. 先つ甲剔後 2 週目の血液「ア」量の變化は A

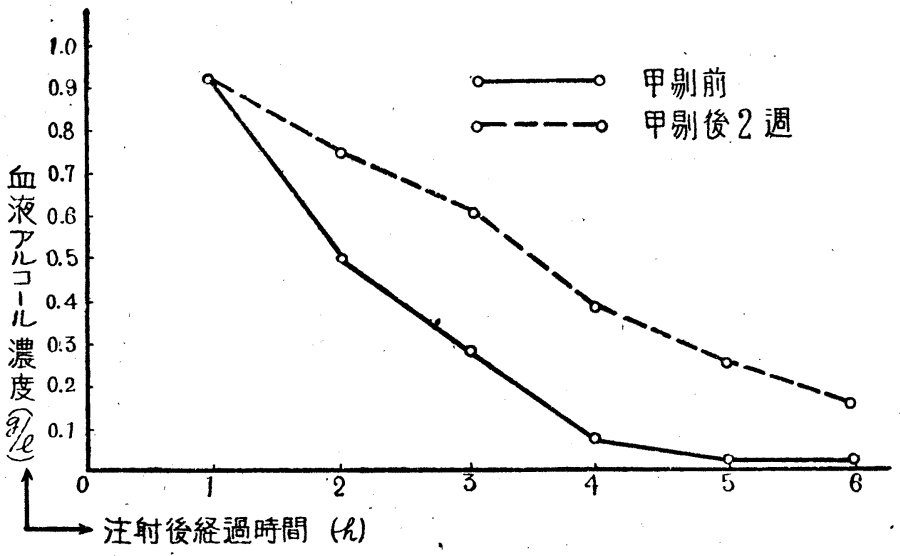

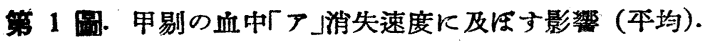

に於ける實驗成績と略同樣で，平均に於て $\beta$ 值は略 $22 \%$ 減，酸化係數は $22 \%$ 減であり，因子 $\mathrm{r}$ は略同一值を示 してるる，之にThyroxin 投與をすると第2圖に示す等に，本均では「ア、注射後最初の $1,2^{\mathrm{h}}$ 目は甲剔前及び甲剔

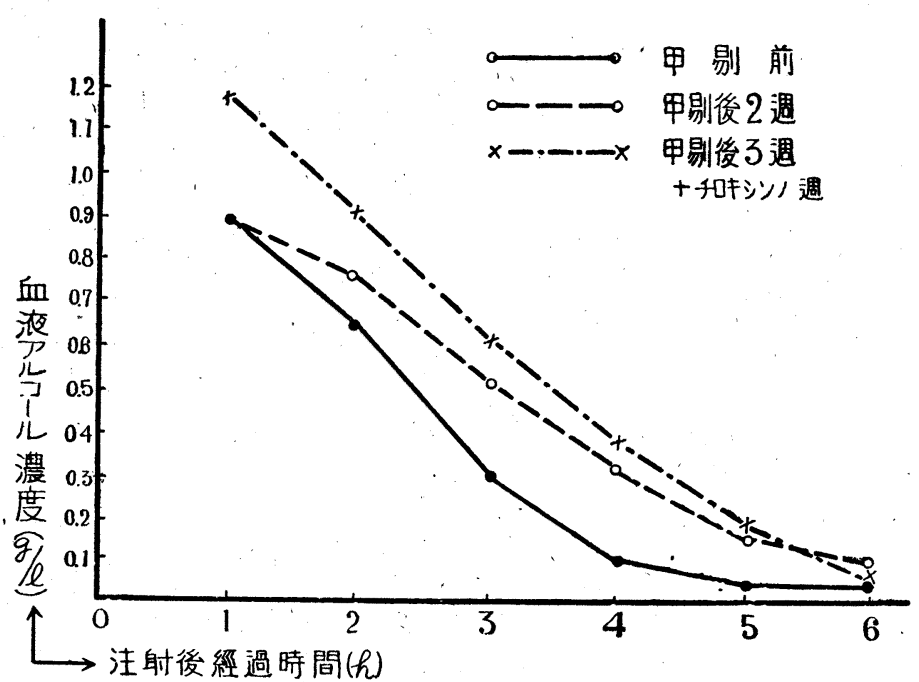

第 2 回. 甲剔後チロキシンを投與した場合の血中 $「 ア 」$ 量の消長, 實驗 B の本均.
後 2 週目の值に比し稍高値を示し てるるが，漸次時間的絓過と共に 急勾配を以て甲剔後の值に接近し 第 $6^{\mathrm{h}}$ 目には略甲剔前の值に近接 して來る. 又附表の $B$ に示す如く ～の 平均值は全く甲剔前の值に一 致して來る. 但し， $\mathrm{C}_{0}$ が著しく高 值を，從つて エか低值を示して來 る篇めに酸化係數は甲剔後 2 週目 の值とほぼ同樣である.

（實驗C) 甲剔後 1 週目より 1 週 間 Thyroxin を連續注射した場合: 4 例の家鬼に就き此の實驗を施行 した成績は第 3 圖及び附表のCの 如くである. 郎ち甲剔後と雖す 1 週間目より Thyroxin 支連續 1 週 間投與した場合には，血中「ア」の

消失速度は正常時より崽ろ促淮される程である.その證左として $\beta$ 值が甲剔前よりも概して著しい增加を示して ある (附表の C 照). 酸化係數は 4 例平均では $12 \%$ 增である. 然し年ら，其の後更に 2 週間 Thyroxin 投與を 中止して「ア」負荷試驗を行ふと $\beta$ 值は再び甲剔前に比し著明な減少を示し，本均値では19\%減で Thyroxin 投與 時の值に比し實に35\%減である．酸化係數も亦甲剔前に比し11\%，Thyroxin 投與時のそれに比し 17\%の減少で ある. 是等は何れもAに於ける實驗成績と共通する結果を示して属る.

佾動物の一般狀態に就ては僅か 1 週間の Thyroxin 注射に依つて動物は一般に元氣恢復し運動狀態も活潑で，

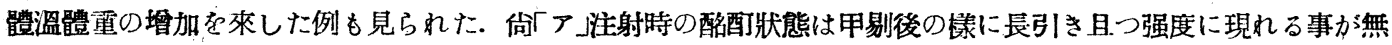
く㸘ろ正常より早く酪酊から醒め其の强度も略正常と同樣であつた. 
甲狀腺機能と「ア」代謝との關係 に關する ると, 被检動物, Thyroxin の適用 量, 部位站に时期, 負荷「ア」適用 方法等の各種賽驗條件の相違等に より，必すしも一定の結論に到達 して居らぬものと思はれる. 余の 行つた Thyroxin の投與方法は適 用方法立に作用の潛伏期，持續性 及び蓄積等25)總ゆる點から考へて 妥當であると信する.從つて正常 動物に Thyroxin 支投與して行つ た諸家3-10)の實驗よりも，余の場 合の方が滛に合理的であり，文其 戌績も信ずるに足るものである.

郎ち，余の實驗から甲剔により 注入「ア」の血中よりの消失速度 $\beta$

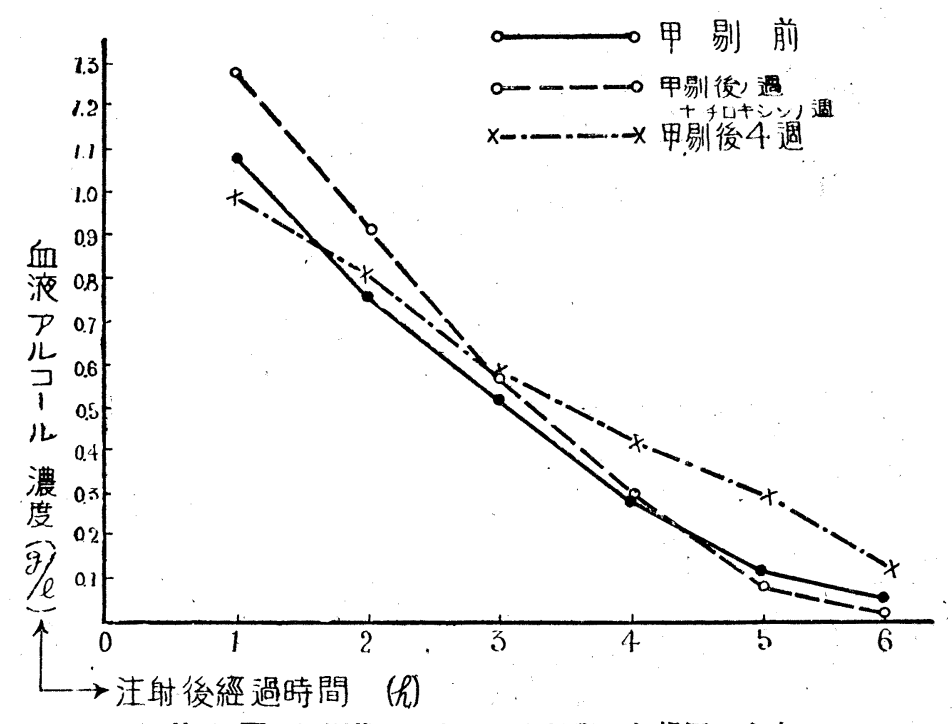

第 3 回. 甲剔後チロキシンを投與した場同の血中 $「 ア$ 量の消長，實驗 $\mathrm{C}$ ○本均.

站に酸化係數は著しく減少し，由剔後と雖もThyroxin 奔投與すれば $\beta$ 立に酸化係數は正常値に近接又は一致す るは確かである.

抆て，血中「ア」消失速度が甲剔により著明に減少した機轉を究明しょう。之には「ア」の組織への擴散，體內に

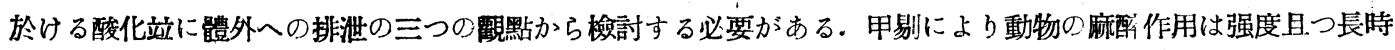
間持續した事實より先づ「ア」の組織中への搌散は異常無く行はれて居るものと思はれる.Thyroxin 投與の時に 於ける酪醇㹜態と「ア」曲線特に其最初の數時間とを比較すると如何にも組織への搌散か煺延して居るかの如く見 えるが，家象では靜注による場合は略 60〜80 $\mathrm{m}$ で擴散本衡に達する事はLe Bret心 ${ }^{26)}$ の既に發表した處である.

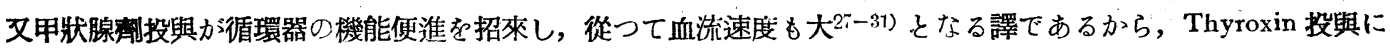
より少くとも「ア」の分布が遲延して來るとは思はれぬ. 但し細胞の唀過性立に體液と細胞との「ア」分配率が本問 題の根底に横はつて居るが，此點に關しては明でない。他方，Thyroxin が生體内組織の酸化能を光進する事は 周知の事實である．以上の諸點から甲剔後に見られる血中「ア溜失速度の減少は體內酸化機能の減退に基〕もの

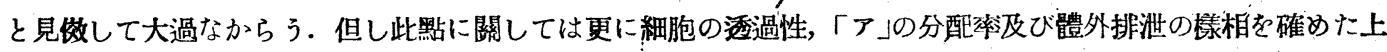
でないと斷定は出來ない.

\section{結 論}

家鬼の甲狀腺を全剔出した後に於ては，血行內に注入された Alkohol の血中よりの消失速度は正常時に比し 著しく退延し Alkohol の麻醉作用も强く且つ長洔間繯く，併し甲狀腺剔'出後と雖も之にThroxin の適當量を皮 下注射すると，Alkohol. 消失速度が正常時或は其以上に促進されれ麻醉の强さ及び持續時間も正常時と變りなくな る. 以上の知見は甲狀腺機能の脫落が Alkohol $\sigma$ 體內酸化に障碍を來した結果と推察される。

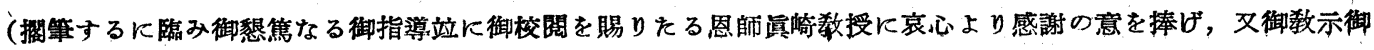
粳掕を屡ふしたる田邊助教授に深謝す), 


\section{引、用書 自}

1) Dell Acqual: Kilin. Wschr. Jg. 13,.1789 (1934).

2) Erwtemann u. Heeres: Zit. n. Ber. Physiol. usw, 110, 236. (1939).

3) Vollmer u. Buchhols: Nannyn-Schmiedbergs Arch. 155, 185 (1930).

4) Rosozskaia Zit. n. Ber. Physiol. usw. 96, 59 (1936).

5) “鵜鸰：岡山監學會雜誌 51,2686 (昭和14年).

6) Widmark: Biochem. Z. 282, 79 (1935).

7) Láng, Sánder u. Béla: Z. exper. Med.99, 81 (1936).

8) Benediot u. Mezey: Biochem. Z. 289, 432 (1937).

9) Schaffer et Le Breton: Zit. n. Abeli: Schweiz. med. Wschr. Jg. 20, 569 (1939).

10) Dontcheff: C. r. Soc. Biol. Paris. 130, 1410 (1939).

11) Grafe : Erg. Physiol. Heft 2, 241 (1923).

12) Küunde: Amer J. Phyiol. 82, 195 (1927).

13)' Smith Greenwood \& Foster: Amer. J/Pathol. 3, 669 (1927).

14) Boothy \& Wilhelmij: Amer. J. Physiol. 97, 506 (1931).

15) Kommerell: Naunyn-Schmicdbergs Arch. 161, 173 (1:31) : Ibic. 165, 169 (1932).

16) 海輸 : Tohoku J. exper. Med. 19, $\subseteq 6$ (1932).

17）鉿居：北越醫學會雜誌 48,515 (昭和 8 年).

18) Trendelenburg: Die Ilormone 2, 121 Berlin (1934).

19) Maier: Zit. n. 18).

20) Asher: Physiologie d. inneren Sekretion 85 Leipzig (1936).

21) Bomskov : Methodik der Hormonforschung 1, 198 Leipzig (1937).

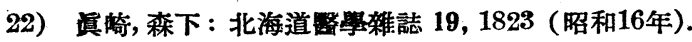

23)" Widmark: Biochem. Z. 267, 128 (1933).

24）水姓：航空需學 2, 255 (昭和20年).

25) Bomskov: Methodik der Hormonforschung, 1, 186 Leipzig (1937).

26）Le Breton: 生理化學研究 47 江上不二夫譯（昭和14年).

27) Blumgart, Herrmau, Samuel, Gargill \& Rourke : Zit n. Ber. Physiol. usw.63, 490 (1932) : Ibid. 59, 280(1931).

28) Ervig u. Hinsberg : Z. klin Med. 115, 677 (1931).

29) Michael u. Buschke: Klin. Wschr. 1592 (1932).

30) Herrick, Essex, Mann u. Baldes. : J. Amer Physiol. 105, 434 (1933).

31) Yater: Zit, n, Neter: Med, Klin, 1129 (1934). 